\title{
A THEORETICAL STUDY DIRECTED AT THE ACCESSIBLE TOURISM MARKET UNDER THE TRAVEL VALUE CHAIN
}

Funda ODUNCUOĞLU1

Esin YÜCEL ${ }^{2}$
Received Date (Başvuru Tarihi): 31/10/2019

Accepted Date (Kabul Tarihi): 02/12/2019

Published Date (Yayın Tarihi):25/12/2019

\section{ABSTRACT}

What lies at the basis of all travel and tourism activities is ensuring that the many different products and services required by the tourist during his / her travels are provided by different organisations and businesses. Value Chain Analysis is a useful technique for the purposes of gaining an understanding of the contents of these products and services, and establishing an associative understanding between the organisations and businesses which provide these. The purpose of this study is to evaluate the accessible tourism market, which is an important market throughout the whole world, under the elements of the travel value chain. In this context, the concepts of accessible tourism, the accessible tourism market and the characteristics of the sub-groups which constitute the market are explained first, followed by an explanation of the concept of the travel value chain and an assessment of the accessible tourism market under the elements of the travel value chain.

Keywords: Accessible Tourism, Value Chain Analysis, Disabled Tourism

JEL Codes: Z32, 112

\section{SEYAHAT DEĞER ZINCİRI ALTINDA ERISŞİLEBİLİ TURİM PAZARINA YÖNELIK KURAMSAL BİR ÇALIŞMA}

$\ddot{O} Z$

Tüm seyahat ve turizm faaliyetlerinin temelinde, turistin seyahati süresince ihtiyaç duyacă̆ çok çeşitli ürün ve hizmetlerin, farklı kurum ve işletmelerce temin edilmesi yatmaktadır. Bu ürünlerin ve hizmetlerin içeriğinin anlaşılması ve bunları sunan kurum ve işletmeler arasında iliş̧isel bir anlayışın oluşturulmasında seyahat değer zinciri analizi faydalı bir tekniktir. Bu çalışmanın amacl, dünya genelinde önemli bir Pazar olan erişilebilir turizm pazarını, seyahat dĕ̆er zinciri unsurları altında değerlendirmektir. Bu amaç doğrultusunda çalışmada öncelikle erişilebilir turizm kavramı, erişilebilir turizm pazarı ve pazarı oluşturan alt grupların özellikleri ele alınmış, ardından seyahat değer zinciri kavramı açıklanarak, erişilebilir turizm pazarı, seyahat değer zinciri unsurları altında değerlendirilmiştir.

Anahtar Kelimeler: Erişilebilir Turizm, Değer Zinciri Analizi, Engelli Turizmi

JEL Kodları: Z32, 112

\footnotetext{
${ }^{1}$ Dr. Öğretim Üyesi, Adnan Menderes Üniversitesi, funda.cengiz@ adu.edu.tr,

${ }^{1}$ Dr. Öğretim Görevlisi, Akdeniz Üniversitesi, esinyucel@ akdeniz.edu.tr,
} 


\section{INTRODUCTION}

Due to their structure, touristic products possess the nature of being combined products. The meaning of this is the need to bring together different products and services, such as transport, accommodation, food and beverage, entertainment, local transport, attractions and tours, under the scope of the touristic products which the person or persons wishing to travel and need to purchase in order to be able to do so (Kusluvan and Karamustafa, 2001). Due to this nature, when performing the marketing activities of touristic products on the national and international platform, there is a need to establish a high level of coordination between, on the one hand, the economic and social factors reliant on demand, and, on the other, the factors which attract demand, such as the touristic attractions, touristic facilities and accessibility, reliant on supply. Ensuring this coordination and harmony as a priority, in the strategies directed at specific tourism markets, is imperative for the success of the businesses (Yoon and Uysal, 2005). One of the specific tourism markets, the importance of which continues to increase, is the accessible tourism market comprised by disabled individuals (Murray and Sproats 1990; Vignuda, 2001; McKercher et al., 2003; Ray and Ryder, 2003).

Accessible tourism is a multi-dimensional and complex type of tourism which requires that, together with universal design, the types and degrees of disability, the needs for support and the suppliers of the products and services need to be taken into account, and includes cooperative processes between stakeholders (Eichhorn and Buhalis, 2011). On the other hand, travel value chain analysis is a useful technique for understanding the content of these products and services and establishing a cooperative conception between the organisations and businesses which provide these. Travel Value Chain Analysis facilitates the perception of travel as a whole and the understanding that any faults and flaws in any one of the parts which constitute this whole, will result in the trip becoming more difficult. In this context, the purpose of the study is to discuss value chain analysis, which is important for businesses to be able to see and sustain their competitive advantages, in terms of the accessible tourism market, which has become a current and priority market due the continuing increase in its importance throughout the world, and which itself is separated into different sub-groups, and present a general framework in the dimensions of both the industry and businesses. Accessible tourism and the accessible tourism market is discussed first in the study, in line with this objective, followed by an explanation of the concept of the travel value chain and the assessment of the accessible tourism market under the elements of the travel value chain. 
Despite the continuing increase in the importance of the accessible tourism market, the view that the tourism studies conducted into the subject in the tourism literature are insufficient is dominant (Yau et al., 2004; Richards et al., 2010). From this aspect, it is considered that the study will make a significant contribution to the literature, due to the fact that it deals with both the matters of demand and supply in the travel process of the accessible tourism market.

\section{CONCEPTUAL BACKGROUND}

\subsection{The Accessible Tourism Market}

The concept of accessibility is to determine the level of the relationship of the individual with his / her environment, from the point of view of the level of independence of his / her life and the place of disabled individuals in society. In this context, the accessibility of an environment is related to the capability of an individual with a disability to act in an independent manner within it (Iwarsson and Stahl, 2003). Accessibility is based on the principle of delivering and presenting a product or service to the market in the manner which will ensure that the customer can buy it in the easiest way possible. Customers will buy products or services which they can reach. This is one of the fundamental rules of being in the market.

The type of tourism which covers a presentation and activities directed at the disabled, has been referred to various different statements until today. The most frequently seen notions in the literature are disabled or disability tourism, easy access tourism, barrier-free tourism, inclusive tourism, universal tourism, and lastly, accessible tourism. Accessible tourism, was first used by Darcy and Dickson (2009), within the framework of the conception of the "whole life", with the expectation that every individual may have a permanent or temporary disability at some point in their lives. This concept has been proposed as a statement which covers a wider audience (for example, those with temporary disabilities, families with small children, those who work in unsafe conditions), by emphasizing the universal design understanding, and as a statement which contains the values of independence, equality and respectability. In this respect, the concept which presents the type of tourism that covers the products, services, presentations and activities directed at disabled individuals, in the best and clearest manner, is “accessible tourism” (Darcy and Buhalis, 2011).

Disabled individuals, who are the subject of accessible tourism, are defined by the World Health Organisation (WHO, 2011), as "individuals who have lost the capability to do something which would be deemed to be normal for a person, and / or had their capabilities 
restricted, as a result of an injury or deficiency ... in respect of their health". Disabled individuals are classified in different ways based on the source from which the disability arose or its reasons. When the disabilities of the aged population, which appear with old age, are also considered as a type of disability, there are 7 main types of disability which have been defined (Burnett and Baker, 2001; Buhalis et al., 2005):

1) The physically disabled and individuals who are faced with movement difficulties;

2) The blind and individuals who have visual impairments;

3) The deaf and individuals who have hearing impairments;

4) The dumb and individuals with speech impediments;

5) The mentally handicapped and individuals with learning difficulties;

6) Individuals with hidden and / or long term health problems;

7) Aged individuals.

On the other hand, universal accessibility and universal design deal with the subject within a wide framework which contains everyone with a relationship with all touristic products, services and their environment, and women who are pregnant or breast-feeding, obese tourists, families travelling with babies or small children, tourists who require assistance carrying their luggage and tourists who are faced with language difficulties in the country or region they visit, in addition to the types of disabilities set out above, under accessible tourism. Disabled individuals need support in order to overcome the problems they may be faced with, in connection with their disabilities, during their trips. Therefore, when they travel, they do so together with an individual or individuals who are able to assist them (Buhalis et al., 2005; Vignuda, 2001; McKercher et al., 2003; Ray and Ryder 2003). When the family members, friends, private carers, etc. who accompany disabled individuals during their trips added to the total disabled population throughout the world, the size of the potential accessible tourism market is estimated at 133 million. This figure indicates that, on average, 10 out of every 100 people living in the world, has a need for accessible travel (ITB 2012; ENAT, 2012). In actual fact, whether they are disabled or not, when it is considered that all individuals need a certain level of accessibility in order to meet their requirements for comfort and quality during their trips, it can also be said that this figure is above that which has been estimated (Buhalis et al., 2005; Vignuda, 2001; McKercher et al., 2003; Ray and Ryder, 2003).

Academic studies based on increasing the relationship of disabled individuals with travelling and tourism have concentrated mainly on the barriers faced by disabled individuals 
during their holidays. According to McKercher et al. (2003), the factors which influence the tourism activities of disabled individuals are separated into two groups - internal and external factors. Table 1 lists the sub-factors for these two factors and the components of them. The internal factors which prevent disabled individuals taking part in tourism activities are described under two groups - individual and economic factors. On the other hand, the external factors are stated as environmental and communication related factors (McKercher et al., 2003).

Table 1. Effecting Factors of Tourism Behaviour of the Disabled People

\begin{tabular}{|l|l|l|l|}
\hline \multicolumn{2}{|c|}{ Internal Factors } & \multicolumn{2}{c|}{ External Factors } \\
\hline \multicolumn{1}{|c|}{ Individual } & \multicolumn{1}{|c|}{ Economic } & \multicolumn{1}{c|}{ Environmental } & Communication Related \\
\hline - Lack of knowledge & - Financial capabilities & - Architectural & -Insufficient or \\
- Unsuccessful social life & - Income inequalities \\
- Health problems & $\begin{array}{l}\text { - The need for a } \\
\text { companion and being } \\
\text { - Psychological or physical } \\
\text { disabilities }\end{array}$ & $\begin{array}{l}\text { geographical suitability } \\
\text { able to meet their } \\
\text { expenses }\end{array}$ & $\begin{array}{l}\text { - Rules and regulations } \\
\text {-Communication } \\
\text { difficulties }\end{array}$ \\
- Deeming it suitable to & - Safety & $\begin{array}{l}\text { - Lack of encouragement } \\
\text { for participation }\end{array}$ \\
\end{tabular}

Source: McKercher et al., 2003.

\subsection{The Travel Value Chain}

Value is stated as the price consumers are prepared to pay in return for the benefit a business provides them. The matter of whether a business is competitive or not depends, to a large extent, on the value it creates (Busbin et al., 2008). The sustainability of competitive advantage can be ensured as a result of a business implementing a strategy which is not simultaneously implemented or copied by its existing and potential competitors. The examination of all of the activities of a business and the interaction between these activities, and the presentation of the basic competences, are necessary in order to analyse the sources of competitive advantage. Value chain analysis is one of the fundamental tools used in the realisation of this in a fundamental manner. 
The value chain expresses all of the operations which are required from the notional design of a product or service, to its delivery to the final consumer. It assists in determining the position of the business in the market, and the understanding by businesses of all of the set of activities (added together), which are required for them to ensure competitive advantage.

According to the World Disability Report (2011), the "travel value chain" includes all of the parts to which added value has been added, from the starting point of the trip, to its conclusion. If one part is inaccessible, then it is stated that this will cause the whole trip to become more difficult. A travel value chain model directed at an accessible tourism market, showing the manner of the relationship between numerous components, can be seen in Figure 1.1.

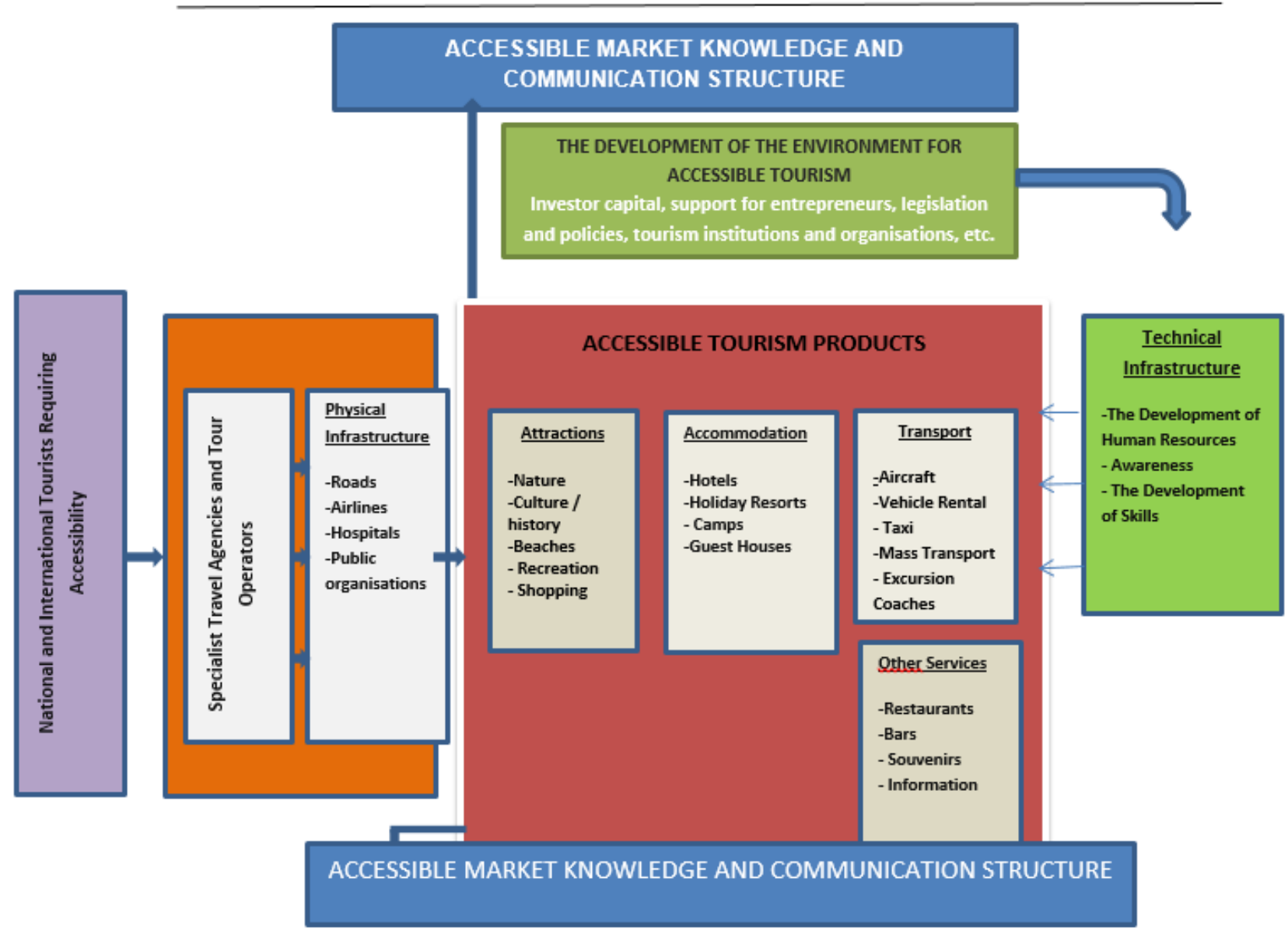

Figure 1. Accessible Tourism Travel Value Chain Model

Source: Buhalis, D. at al., 2012. 


\section{3. Assessment of the Accessible Tourism Market from the Aspect of the Travel}

\section{Value Chain}

When the existing studies conducted on the subject are examined, it can be seen that disabled individuals are faced with numerous problems in terms of participation in tourism activities. Despite the fact that it is widely accepted that each individual - whether disabled or not - has holiday needs of a similar degree (Yau et al., 2004), it can be said that the opportunity of disabled individuals to participate in tourism are much lower than those of individuals who are not disabled, due to accessibility restrictions (Turco et al., 1998). If these barriers, which are faced by disabled individuals, are removed, then there will be an increase in their rates of participation in tourism activities (McKercher et al., 2003).

The matter which needs to be paid attention to as a priority in the provision of accessible services to disabled individuals is a complete understanding of what accessibility involves. While the provision of suitable physical conditions to disabled individuals for accessibility constitutes the basis for this concept, the concept expresses a comprehensive notion related to all other facilities which may be needed based on the type of the disability, as well as websites, written documents, signs, communication and transport, rather than just physical facilities (McKercher et al., 2003). In this context, the matter of accessibility directed at disabled individuals needs to be dealt with on the levels of destination and country in general, rather than just business organisation, for all types of products and services which may be required, over and above physical conditions and facilities. On the other hand, when the accessible tourism market is considered as a whole, which has been created by different and interrelated components, the travel value chain will bring an intelligible point of view, which is directed at developing a competition to all of the service providers. Accessible tourism has been examined in the manner set out below, under each element of the travel value chain.

\subsubsection{Accessible Market Knowledge and Communication Structure}

The first and most important link of the accessible tourism travel value chain is the establishment of a healthy structure of knowledge and communication within the market. The success and sustainability of all of the other links within the chain will be possible once this structure has been ensured in a correct and active manner. When the academic studies directed at the importance of knowledge and communication for accessible tourism are examined, the matters which stand out first can be listed as the establishment of a structure of knowledge 
and communication in line with the characteristics of the different sub-groups, due to the heterogeneous structure of the market, the correctness and intelligibility of the information, the availability of possibilities of easy access to the sources of communication and knowledge, the establishment of an infrastructure of knowledge and communication by the destination, within itself and the regular updating of information (Buhalis et al., 2005; Buhalis and Michopoulou, 2011; Kim and Lehto, 2011). The matter which must not be overlooked among these is that the travel process is more complex and difficult for a disabled individual, than for a normal individual, from the start to the finish. This difficult process begins with the desire of the disabled individual to participate in tourism in person, and continues with him or her evaluating himself or herself and what he or she can do, based on his/her disability. After this evaluation, he/she will obtain reliable information concerning the holiday locations and types most suited to him/her, and manage and experience his/her trip in accordance with the information he/she has obtained (Yau et al., 2004).

The existence of accessible knowledge increases the decisiveness for and frequency of travel of disabled individuals. As a result of the study conducted by Buhalis et al. (2005) on the importance of knowledge in accessible tourism, they reached the conclusion that a disabled individual would take more than one trip during a year if he/she had reached correct and accessible knowledge concerning his/her trip. The division of a market group with these characteristics into sub-segments when establishing accessible knowledge and the infrastructure to transfer this knowledge through the most correct channels, is another matter of priority for the purposes of increasing satisfaction, competition and sustainability. In the study conducted by Oppenheim and Selby (1999) on the accessibility of knowledge to deaf and visually impaired individuals on tourism websites, it was concluded that the motivation to travel had fallen as a result of the lack of specially designed websites, directed at these individuals and that the required knowledge could not be provided. As a result of the study conducted by Kim and Lehto (2011), on the complaints of disabled tourists concerning websites, it was stated that the most important complaints were related to incorrect and deficient information as well as the fact that there was no possibility to make special requests and that there was a lack of authorised staff who could be contacted.

\subsubsection{Specialist Travel Agencies and Tour Operators}

Two important alternatives used by the disabled when organising their trips are travel agencies and tour operators. Travel agencies are able to perform a number of different procedures, from the transport of the disabled tourists to their accommodation. Some travel 
agencies also organise tours and excursions directed at the special needs of the disabled. However, it is seen that certain difficulties are also experienced in the event that the disabled choose travel agencies. Travel agencies are not able to organise tours and excursions which meet all of the needs of the disabled. The reason for this is that, despite the fact that tourism businesses, such as accommodation providers and restaurants, have declared that they are accessible, in reality they are not. Another difficulty in connection with travel agencies is that they do not have sufficient infrastructure and experience on the subject of disabilities. Apart from travel agencies, disabled tourists are also able to organise their trips through tour operators. In different countries, there are tour operators who only organise tours directed at the disabled. These tour operators offer disabled opportunities of tours based on different types of disabilities. Cavinato and Cuckovich (1992), state that as the tour operators which organise tours directed at the disabled have themselves generally been established by disabled individuals, they are in a position to provide services with a better understanding of the needs of the disabled. However, certain problems may still be faced in the organisation of trips through these types of tour operators. In particular, the fact the tour operators do not organise tours or excursions until the required number of participants has been reached, results in issues to do with planning and timing for disabled individuals. In addition to this, other matters of importance in the holiday planning and reservations of disabled individuals are the presence of knowledgeable and helpful staff for reservations and call centres, with which disabled individuals are to communicate, being sensitive to the needs of the disabled (Veitch and Shaw, 2011).

\subsubsection{The Accessible Tourism Product}

The fundamental problems within the scope of the products - benefits to be developed directed at this market group arise from stereotype thinking directed at disabled individuals (Fleischer and Pizam, 2002). There is no doubt that disabled individuals have specialised needs for products based on the type of disabilities they have. For instance, while a special parking space or hotel room which has been fitted appropriately for his / her disability, for a physically disabled individual, maybe a successful approach on the scale of creating a suitable product, it may not create benefit. The reason for this is that, contrary to what is believed, what lies beneath the expectations of disabled individuals directed at their trips, are the basic motivating factors of rest, entertainment, socialising and seeing new places - just like everyone else - and that this fact is overlooked (Burnet and Baker, 2001; Fleischer and Pizam, 2002; Rice, 2006). 
The accessibility of a tourism product relies on the basis of individuals being able to easily reach all of the elements which create value for tourists and motivate them to travel, on the national and international level. Academic studies in recent years have revealed that disabled individuals need to be separated into very different groups according to their experiences, points of view and needs based on their type of disability (Fleischer and Pizam, 2002). In this context, the common conclusion reached by studies is the need to present individualised products and services, by separating the disabled individuals who constitute the target market into target groups in the most correct manner possible, in order to be able to offer these groups appropriate and satisfactory tourism products and services. Tourism businesses need to evaluate the different types and levels of disability while developing products and services in order to be able to reach this market directly (Buhalis et al., 2005).

According to a study conducted on disabled tourists who visited England in 2003, found that, contrary to what was expected, disabled individuals preferred standard accommodation providers providing tourism services to the masses, rather than those offering special services directed at the disabled, for their holidays. The reasons why the participants did not choose the accommodation providers offering services directed at disabled individuals were, primarily their high prices and the fact that there were discriminatory practices and the individuals accompanying the disabled individuals would need to stay elsewhere (ENAT INOP Visit Britain, 2003). Further, according to the results of the study, the participants who took part in it stated that they would happily pay additional fees for any technical equipment and services provided by the standard accommodation providers, to them.

On the other hand, according to the results of a study conducted by Shaw and Coles (2004), on the barriers to the trips of disabled tourists, economic restrictions constitute a big barrier for these individuals as physical accessibility. The researchers have stated that financial restrictions are just as important issue as physical barriers, in disabled tourism. In their study, Burnet and Baker (2001), stated that pricing decisions are very important for the disabled, but that it would not be possible for businesses to reach this market with low quality products and services in order to be able to offer lower prices.

\subsubsection{Physical Infrastructure}

The presence of physical infrastructure is important in the choice of destination by disabled individuals. In the event that disabled individuals are unable to find suitable 
infrastructure facilities, they may change their preferred destinations or cancel their trips (Darcy and Pegg, 2011).

Among the elements of physical infrastructure is the accessibility of roads at a local and national level, airports, hospitals, public organisations and similar services. Accessibility, which means being able to reach the economic, social and cultural environment, and in particular the physical and natural environment, and benefit from the services provided in these areas, is also a mandatory condition of being able to use rights and freedoms in full. Therefore, in recent periods, states and international organisations have brought the perception of accessibility to the fore in their activities in the field of human rights, and accept this as a fundamental principle from the point of view of realising rights and freedoms. The biggest problems faced by disabled individuals at destinations are the lack of physical arrangements, the presence of architectural barriers, a lack of the equipment needed by the disabled and the failure to provide the necessary services in a timely manner. This prevents disabled individuals from being potential customers for destinations (European Commission, 2004).

Some of the physical infrastructure problems determined by the Barrier-Free Tourism Committee of TÜRSAB (the Association of Turkish Travel Agencies) can be listed as follows:

- A lack of sufficient vehicles of mass transport suitable for disabled use;

- The fact that the design of the places worth visiting in the town or region, the museums and archaeological sites, have not been designed suitably for the disabled;

- A lack of free parking opportunities and appropriate signs directed at the disabled;

- A lack of telephone boxes suitable for use by the disabled;

- Difficulties faced due to a lack of spatial structures where foreign guests, who are visiting our country with their own cars, are able to have their procedures performed with ease, at the border gates;

- The insufficiency of fixtures which would enable the disabled from benefiting from the services in public buildings such as hospitals, community clinics and police stations, which also serve tourists;

- The lack of competent authorities and locations to which the disabled can apply in the event of problems (TÜRSAB, 2008). 
The Ministry for Culture and Tourism also published a Circular concerning "BarrierFree Tourism", in 2011, which emphasised that an environment with an accessible structure, which had been designed at universal dimensions for different human situations, would contribute to the freedom to travel and tourism of everyone, and recorded that important roles and responsibilities needed to be assumed by both local administrations and the private sector, as well as central government.

\subsubsection{Technical Infrastructure}

Technical Infrastructure is based on the principle of creating awareness among local and national level, directed at tourism in general and disabled individuals in particular, and the training and development of the human resources which will provide services directed at this market group, from the accessibility point of view.

In the study conducted by Rice (2006), with the aim of determining the differences in the levels of knowledge possessed by hotel managers in connection with disabled tourists, he reached the conclusion that managers did not have an accurate or consistent view of what was needed to meet the needs of disabled tourists, and that what is more, they did not possess any significant or different point of view concerning the market. When it is considered that the correct information can only be provided by businesses which understand this market correctly, the primary step in order to be able to successfully implement this part of the chain, is the requirement to establish an awareness directed at disabled individuals at these organisations. Apart from this awareness, the presence of trained staff, directed at the issues faced by disabled individuals, in contrast with other individuals, before, during and after their holidays, and their demands and needs which arise as a result of these issues, will both increase their participation in tourism and ensure their loyalty to the organisation (Yau et al., 2004).

In the study conducted by Grady and Ohlin (2009), they found that the complaints directed at the accommodation providers of $60 \%$ of the disabled tourists who took part in the study were related to customer relations and the lack of competence of their staff. Similarly, in the study conducted by McKercher et al. (2003), the participants pointed to the negative attitudes of the personnel in the travel and accommodation industry as one of the biggest barriers in front of accessibility.

The expectations of 27 visually impaired individuals from tourism activities were asked in the study conducted by Richards et al. (2010). According to this study, the visually 
impaired individuals want the staff employed in tourism businesses to be trained on the subject of disability and for businesses to be physically adequate for the visually impaired. The failure to meet these requirements leaves disabled individuals out of tourism activities (Richards et al., 2010: 1103-1111).

\subsubsection{The Development of the Environment for Accessible Tourism}

According to Smith (1987), there are three principal factors which prevent the disabled from performing tourism activities. The first of these are environmental factors. Environmental factors are described as attitudinal, architectural and ecologic barriers. Attitudinal barriers express the attitudes of the destination and tourism businesses concerning the realisation of the practices required for the disabled to be able to act freely, while architectural barriers refer to the barriers arising from physical structures and ecologic barriers the formations arising from the natural structure of the region (steep hills, rugged land structure, etc.).

The development of the environment for disabled tourism covers the development of the capital structure of the investors who wish to provide services in this area, the support of entrepreneurs, the preparation and implementing of legislation and policies directed at accessible tourism, ensuring accessibility by creating awareness among tourism organisations and institutions and the realisation of activities directed at developing accessibility. Numerous innovations and improvements at both the legal and environmental level, directed at supporting the development of the disabled market - the importance of which continues to increase throughout the whole world - are being undertaken (Burnett and Baker, 2001; Richards et al., 2010).

The significant share of disabled individuals within the world population has lead to countries and organisations being more sensitive to the right of travel of these individuals and to activities directed at increasing their mobility and making it easier (Burnett and Baker, 2001). The Manila declaration, which was published by the World Tourism Organisation in 1980 , states that, "The ultimate aim of tourism is to develop the quality of life and create better living conditions for everyone" (UNWTO, 2005). After the World Tourism Organisation, in 1996, the European Commission similarly adopted a sensitive approach to the sector, with the slogan, "Tourism for Everyone", and drew attention to the meeting of the needs of disabled tourists and families and the economic potential of this market, in the handbook it published (Var et al., 2011). While the studies published by organisations contain 
information concerning the development of the participation of disabled individuals in touristic activities, information sources and transport and accommodation facilities, certain countries have moved in the direction of passing their own regulations on this matter. The United States of America implemented the Americans with Disabilities Act (ADA) in 1990, and this was followed by the Disability Discrimination Act (DDA) in the United Kingdom, in 1995. Both acts play a very important role for the tourism industry in particular (Miller and Kirk, 2002).

Governments have a responsibility for ensuring disabled tourism opportunities for the disabled. The disabled have begun to travel more following the implementation of effective legislation - which had been neglected for years - in many countries and the impact of these laws beginning to show. Certain regulations were also passed by the Ministry of Tourism, in our country, in 1991, in order to improve the standards of living of disabled individuals either living in or visiting our country, within the scope of tourism. There are also certain other regulations covering the disabled and tourism, apart from those passed by the Ministry. The first and most important set of regulations in the legal respect was the signing of the Convention on the Rights of Persons with Disabilities, of the United Nations. The rights of the disabled throughout the world were voiced with this Convention, and the thought of "Barrier-Free" tourism started to become more widespread after this. Following the acceptance of the UN Convention on the Rights of Persons with Disabilities, the World Disability Foundation (WDF), one of the non-government organisations related to the subject, accepted the "Accessible City Regulation" in the context of the 2012 Barrier-Free Living Project Year, within the scope of the Projects of the World disability Union, in 2012, with the aim that it be implemented in the member countries of the UN, led by a Pilot City implementation in Istanbul. The headings of open areas, semi-open areas, closed areas, town furnishings, the mass transport system, the provision of information, signage and the placing of technical arrangements on perceivable surfaces were placed under the project, in order to ensure a full and effective participation by the disabled and aged in the community, and activities for the performance of this work began (World Disability Foundation, 2012).

\section{CONCLUSION}

When the academic studies directed at the relationship of disabled individuals with travel and tourism are examined, it can be seen that the total population of disabled individuals who travel does constitute an important market group (Murray and Sproats 1990; Vignuda, 2001; McKercher et al., 2003; Ray and Ryder, 2003). While it has been accepted 
that this undeniably large group does create new opportunities for the tourism industry (Bi et al., 2007; Daniels et al, 2005; Darcy et al., 2010), the view that the studies concerning tourism on disabled individuals are insufficient is dominant (Richards et al., 2010). What is more, while the studies which have been conducted to emphasise the subject that disabled individuals are neglected and the importance of this segment for the tourism industry, attention is drawn to the fact that there are still serious deficiencies in the literature on the matter of specialised studies which deal with accessible tourism from different angles (Muray and Sproats, 1990; Yau et al., 2004; Buhalis and Darcy, 2011).

Based on these deficiencies in the literature, this study discusses accessible tourism in a wide framework, from the point of view of both supply and demand, and utilises travel value chain analysis for this purpose. Each element of the chain has been examined from a theoretical point of view, in the study. The conclusions of the study on the subject as a result of these examinations have found that there are still important shortcomings in the relationship and coordination, which need to be established between the business organisation and the disabled individual, in the accessible tourism travel value chain. In order to be able to reach this market group, it is essential for each link within the chain to be in complete concordance and cooperation, both within itself and with the other links of the chain. A hotel which has been designed directed at the disabled has no chance of success in a touristic destination where the infrastructure does not comply with accessibility criteria, and it is clear that a disabled individual who stays at this hotel will be dissatisfied with his/her holiday as a result of the problems he/she experiences at the destination. The study is of importance because it provides an extensive point of view of tourism and reveals just how wide an angle accessibility needs to be dealt with from, by utilising the travel value chain, in contrast with other studies. It's most important restriction is that the subject has been examined theoretically and that it has not presented it in a clearer manner, with a practical application in parallel to the theory. It is recommended that future studies, the researchers develop studies directed at an application which deals with the elements constituting the accessible travel value chain, at an associative dimension within themselves. 


\section{REFERENCES}

Bi, Y., Card, J. A. and Cole, S. T. (2007). Accessibility and attitudinal barriers encountered by Chinese travellers with physical disabilities. International Journal of Tourism Research, 9(3), 205-216.

Burnett, J. J. and Baker, B. H. (2001). Assessing the travel-related behaviors of the mobility-disabled consumer. Journal of Travel Research, 40, 4-11.

Buhalis, D. and Darcy, S. (2011). Accessible Tourism: Concepts and Issues (Aspects of Tourism). ISBN 1845411609, Channel View Publications, USA.

Buhalis, D., Darcy, S. and Ambrose, I. (2012). Best Practice in Accessible Tourism: Inclusion, Disbility, Ageing Population and Tourism. ISBN:-15 978184541 2531, Chanel View Publication, USA.

Buhalis, D., Eichhorn,V., Michopoulou, E. and Miller, G. (2005). OSSATE Accessibility Market and Stakeholder Analysis, 1-88, from: [http://www.accessibletourism.org/resources/ossate_market_analysis_public_final.pdf], Date of Access: 18.09.2019.

Buhalis, D. and Michopoulou, E. (2011). Information-enabled tourism destination marketing: Addressing the accessibility market. Current Issues in Tourism, 14(2), 145-168.

Busbin, J.W., Johnson J. T. and DeConinck J. (2008). The Evolution of Sustainable Competitive Advantage: From Value Chain to Modular Outsource Networking. Competition Forum, 6(1), 103-108.

Cavinato, J. L. \& Cuckovich, M. L. (1992). Transportation and tourism for the disabled: An assessment. Transportation Journal, 3(31), 46-53.

Daniels, M.J., Rrodgers, E.B.D., Wiggins, B.P. (2005). Travel Tales: An Interpretive Analysis of Constraintsand Negotiations to Pleasure Travel as Experienced by Persons with Phsical Disabilities. Tourism Management, 26, 919-930

Darcy, S., Cameron, B. and Pegg, S. (2010). Accessible Tourism and Sustainability: A Discussion and Case Study. Journal of Sustainable Tourism, 18(4), 515-537.

Darcy, S. and Dickson, T. (2009). A Whole-of-Life Approach to Tourism: The Case for Accessible Tourism Experiences. Journal of Hospitality and Tourism Management, 16(1), 32-44.

Darcy, S. and Pegg, S. (2011). Towards Strategic Intent: Perceptions of Disability Service Provision Amongst Hotel Accommodation Managers. International Journal of Hospitality Management, 30, 468-476.

Eichhorn, V. and Buhalis, D. (2011). Accessibility - A Key Objective for the Tourism Industry. IN Buhalis, D. \& Darcy, S. (Eds.) Accessible Tourism: Concepts and Issues, (pp. 46-61). Bristol: Channel View Publications, USA.

ENAT-European Network for Accessible Tourism (2012). The Underestimated Market Potential of Barrier-free Tourism, World Travel Monitor Forum, Pisa. [http://www.accessibletourism.org/resources/enat-theunderestimated-market.pdf]. Date of Access: 18.09.2019.

ENAT INOP Visit Britain. (2003).

From http://www.accessibletourism.org/resources/enat_study_1_rights_final_en.pdf. Date of Access: 18.03.2019.

European Commission. (2004). European disability strategy 2010-2020: A renewed commitment to a barrierfree Europe, no. 636 [http://eur-lex.europa.eu/oj/direct-access.html]. Date of Access: 18.07.2017.

Fleischer, A. and Pizam, A. (2002). Tourism constraints among Israeli seniors. Annals of Tourism Research, 1(29), 106-123.

Grady, J. and Ohlin, J.B. (2009). Equal access to hospitality services for guests with mobility impairments under the Americans with Disabilities Act: implications for the hospitality industry. International Journal of Hospitality Management, 28, 161-169.

ITB Berlin. (2012). World travel trends report 2012/2013. Retrieved from http://www.itbberlin.de/media/itbk/itbk_media/itbk_pdf/WTTR_Report_2013_web.pdf. Date of Access: 18.09.2019.

Iwarsson S. and Ståhl, A., (2003). Accessibility, usability and universal design--positioning and definition of concepts describing person-environment relationships, Disabil Rehabil, 25(2), 57-66. 
Kim, S. and Lehto, X. Y. (2011). The voice of tourists with mobility disabilities: insights from online customer complaint websites. International Journal of Contemporary Hospitality Management, 24(3), 451-476.

Kuşluvan, S. and Karamustafa, K. (2001). Türkiyede Dış Aktif Turizmin Gelişmesinde Yabancı Tur Operatörlerinin Rolü, Pazarlama Dünyası, 16(5), 18-28.

McKercher, B., Packer, T., Yau M. K. and Lam, P. (2003). Travel agents as facilitators or inhibitors of travel: perceptions of people with disabilities. Tourism Management, 24(4), 465-474.

Miller, G. and Kirk, E. (2002). The Disability Discrimination Act: Time for a stick?. Journal of Sustainable Tourism, 10(1), 82-88.

Murray, M. and Sproats, J. (1990). The disabled traveller: Tourism and disability in Australia. Journal of Tourism Studies, 1(1), 9-14.

Oppenheim, C. and Selby, K. (1999). Access to information on the World Wide Web for blind and visually impaired people. Aslib Proceedings, 51(10), 335-345.

Ray, N. M. and Ryder, M. E. (2003). Ebilities tourism: An exploratory discussion of the travel needs and motivations of the mobility-disabled. Tourism Management, 24, 57-72.

Rice, P. (2006). Universal Management: a Proposal to Change the Direction of Accessibility Management in the Australian Tourism Industry to Create Benefits for all Australians and Visitors to Australia. The Review of Disability Studies: An International Journal, 2(2), 64-79.

Richards V., Pritchard A. and Morgan N. (2010). (Re)envisioning Tourism and Visual Impairment. Annals of Tourism Research 37(4), 1097-1116.

Shaw,G. and Coles, T. (2004). Disability, Holiday Making and the Tourism Industry in the UK: A Preliminary Survey. Tourism Management, 25, 397-403.

Smith, R.W. (1987). Leisure of disabled tourists: barriers to participation. Annals of Tourism Research, 14(3), 376-389.

Turco, D. M., Stumbo, N. and Garncarz, J. (1998). Tourism Constraints- People with Disabilities. Parks and Recreation Journal, 33(9), 78-84.

TÜRSAB. (2008). Dünyada ve Türkiye'de Engelsiz Turizm Pazarı.https://www.tursab.org.tr/tr/engelsizturizm/dunyada-ve-turkiyede-engelsiz-turizm-pazari 487.html. Date of Access: 19.09.2019.

UNWTO (2005). From

http://www2.unwto.org/sites/all/files/docpdf/2005resolutionaccessibletourismforall.pdf. Date of Access: 19.04.2019.

Var, T., Yesiltas, M., Yaylı, A. and Öztürk, Y. (2011). A Study on the Travel Patterns of Physically Disabled People. Asia Pacific Journal of Tourism Research, 16(6), 599-618.

Veitch, C. and Shaw, G. (2011). Disability legislation and empowerment of tourists with disability: The UK case. In Buhalis D. and Darcy S. (Der.) Accessible tourism concepts and issues. 62-71. Bristol Channel View Publications.

Vignuda, J. (2001). Promotion of Barrier-Free Tourism for People with Disabilities in the Asian and Pacific Region. Economic and Social Commission for Asia and the Pacific (ESCAP). Seminar on Sustainable Development of Ecotourism in Pacific Island Countries, November, 17-18, 2001 Suva, Fiji.

World Disability Foundation. (2012). From

http://www.who.int/disabilities/world_report/2011/report.pdf. Date of Access: 19.01.2019.

Yau, M. K., McKercher, B. and Packer, T. L. (2004). Traveling with a disability: More than an access issue. Annals of Tourism Research, 31(4), 946-960.

Yoon, Y. and Uysal, M. (2005). An examination of the effects of motivation and satisfaction ondestination loyalty: a structural model. Tourism Management, 2(6), 45-56. 